\title{
Considerations about electroretinography in dogs
}

\author{
Considerações sobre a eletroretinografia em cães
}

\author{
Arianne Pontes Oriá ${ }^{1}$ Luiz Paulo Lázaro Júnior ${ }^{2}$ Cristiane dos Santos Honsho ${ }^{1}$ \\ Francisco de Assis Dórea Neto ${ }^{1}$ José Luiz Laus $^{3}$
}

\section{- REVISÃO BIBLIOGRÁFICA -}

\section{ABSTRACT}

Electroretinography is a technique used for the objective assessment of retinal function and is useful as an auxiliary diagnostic tool for various ophthalmopathies. We report here information about the indications, components and measurements of the electroretinogram (ERG) and about the flash ERG technique illustrated by the Classic/Standard protocol used in the Ophthalmology Unit of the "Governador Laudo Natel" Veterinary Hospital, Faculdade de Ciências Agrárias e Veterinárias, State University of São Paulo (UNESP), Jaboticabal Campus.

Key words: electroretinography, oscillatory potentials, dog.

\section{RESUMO}

A Eletroretinografia é técnica que acessa objetivamente a função da retina, sendo útil como meio diagnóstico auxiliar para várias oftalmopatias. Este artigo traz informações referentes às indicações, aos componentes $e$ medidas do eletroretinograma (ERG) e à técnica do ERG flash ilustrada pelo protocolo Clássico/Standard, utilizada na Unidade de Oftalmologia do Hospital Veterinário "Governador Laudo Natel" da Faculdade de Ciências Agrárias e Veterinárias (FCAV) - Universidade Estadual Paulista (UNESP) - Campus de Jaboticabal.

Palavras-chave: eletroretinografia, potenciais oscilatórios, cão.

\section{INTRODUCTION}

The electroretinogram (ERG) is the measurement of the active response of several types of retinal cells to a light stimulus previously determined in a protocol (SIMS, 1990; YANASE et al., 1996). It is a useful tool for the differential diagnosis of various ophthalmic diseases in small animals (RUBIN, 1967; GUM et al., 1984).

The ERG establishes the function of the structures visualized by ophthalmoscopy, a property that is not shared by the other electrodiagnostic techniques (SIMS, 1999). Obtaining an ERG is not more complex than obtaining an electrocardiogram. The only obstacles involved are the understanding and interpretation of the waves in relation to the wide gamut of retinal diseases (CARR \& SIEGEL, 1990).

The objective of the present study was to disseminate among interested professionals the fundamental information about ERG as a highly relevant diagnostic tool in Veterinary Ophthalmology.

\section{Indications of the ERG}

The ERG has been useful for the diagnosis and evaluation of retinal function in dogs in the presence of cataract, hemeralopia, intoxications, sudden acquired retinal degeneration, and cortical blindness (VAN DER WOERDT, 1991; SIMS, 1999). It also permits the study and early and differential diagnosis of hereditary retinal degeneration. Some examples are cone and type 1 and 2 rod dysplasia in Setters and Collies, rod dysplasia and early retinal degeneration in Elkhounds, progressive cone and rod

\footnotetext{
${ }^{1}$ Graduate students Veterinary College, São Paulo University (UNESP), Jaboticabal, SP, Brazil.

${ }^{2} \mathrm{MD}$ - Oftalmoclínica Copacabana, Rio de Janeiro, RJ, Brazil.

${ }^{3}$ Professor, DVM PhD, Veterinary College, UNESP, Jaboticabal, SP. Brazil. Via de acesso Prof. Paulo Donato Castellane, s/n, 14884-900, Jaboticabal, São Paulo, Brazil. E-mail: jllaus@fcav.unesp.br. Tel: 551632092626 - Fax: 55163202 4275
} 
degeneration in Cocker Spaniels and Labradors, photoreceptor dysplasia in Schnauzers, hereditary cone degeneration in Malamuths, congenital stationary night blindness in Briards, and progressive retinal atrophy in Tibetan Terriers, Dachshunds and Portuguese Swimming dogs (AGUIRRE \& RUBIN, 1971; AGUIRRE \& RUBIN, 1972; AGUIRRE RUBIN, 1975; WOLF et al.,1978; MILLICHAMP et al., 1988; PARSHALLet al., 1991).

For some retinal affections involving degeneration, the ERG provides an early diagnosis compared to ophthalmoscopy or to behavioral evaluation tests (SIMS, 1999). The ERG is indicated for the diagnosis of retinal diseases in cats, such as non-inflammatory retinopathies, hereditary retinal degenerations and central retinal degenerations due to dietary taurine deficiency (SIMS, 1999).

\section{Component analysis}

The most important components recorded by the ERG are the "a" wave, the oscillatory potentials, and the "b" wave. The "a" wave, negative deflection, corresponds to hyperpolarization of retinal photoreceptors such as cones and rods (CARR \& SIEGEL, 1990; YANASE et al., 1995; KOMAROMY et al., 1998a). The rods exert a more effective function than the cones in environments of low luminosity or scotopic, being therefore specialized for night vision. They provide low visual resolution in the various grey tones, but are useful for the detection of movement. In contrast, the cones are specialized for daytime or photopic vision and are responsible for color vision, being able to adapt to repeated light stimuli, but being nonresponsive to low levels of illumination (Table 1) (CARR \& SIEGEL, 1990; KOMAROMY et al., 1998a). Because of their different spectral sensitivities, long wavelengths, such as red, are used in clinical practice for the evaluation of cones, and short wavelenghts, such as blue, are used for the evaluation of rod responses (KOMAROMY et al., 1998a).
The oscillatory potentials (OPs) are rhythmic waves that primarily appear in the ERG during the ascending phase of the " $b$ " wave. They originate in the inner plexiform layer (distal to ganglion cells and proximal to receptor cells). Although the ERG and OPs share the same time window, they reflect independent physiological processes (SIMS, 1990; SIMS et al., 1991; BROOKS et al., 1992; SIMS, 1999). As is the case for the ERG, the characteristics of the Ops depend on the intensity, rate and spectral characteristics of the light stimulus and on the state of retinal adaptation and are better recorded with an intense white light stimulus (SIMS, 1990; SIMS, 1999).

The OPs have been used clinically to assess various ophthalmic disorders including diabetic retinopathy, retinal ischemia, pigmental retinal degeneration, chloroquine-induced retinopathy, central artery occlusion and other types of diffuse chorio-retinal degeneration (BROOKS et al., 1992; SIMS, 1999). The " $b$ " wave, positive deflection, follows the "a" wave and is directly related to the activity of Müller cells and indirectly related to bipolar cells (DANTAS, 1995; SIMS, 1999).

The ERG only reflects a limited portion of the activity that occurs in the visual pathway. In the absence of intact ganglion cells and of a normal optic nerve, the retinal signals do not reach the superior centers. Thus, the ERG may be normal even though visual incapacity is present (CARR \& SIEGEL, 1990).

\section{ERG flash}

The primary components of an electroretinography unit are the stimulation systems and the recording (KOMAROMY et al., 1998b). Specific stimuli are provided to the eye, which should be previously monitored with electrodes. The responses obtained are sent to a computer system that records them in the form of graphs.

A corneal electrode shaped like a contact lens is generally used to record the ERG. The ERG

Table 1 - Functional comparison and conditions favoring isolation between cones and rods

\begin{tabular}{lcc}
\hline & Cones & Rods \\
\hline Sensitivity & Photopic & Scotopic \\
Temporal modulation & Follows the rapid flicker & Only the slow flicker \\
& (less than 10/seconds) & Blue-Greene \\
Maximum spectral sensitivity & Yellow - Greene & $(500 \mathrm{~nm})$ \\
Rate of adaptation to dark & $(560 \mathrm{~nm})$ & Slow \\
Color vision & Rapid & Absent \\
& Present & CARR \& SIEGEL, 1990; KOMAROMY et al., 1998a
\end{tabular}

Ciência Rural, v. 34, n. 1, jan-fev, 2004. 
reflects the difference in potential existing between the active (corneal) electrode and the reference electrode placed close to it, usually in the lateral canthus. Electrical interferences are minimized using the ground electrode, differential amplification and purification (filtering) of the response (NARFSTRÖM et al., 1995; KOMAROMY et al., 1998b; SIMS, 1999).

The Classic/Standard flash ERG protocol summarized in Table 2 has been indicated at the Ophthalmology Unit of the "Governador Laudo Natel" Veterinary Hospital of the Faculdade de Ciências Agrárias e Veterinárias (FCAV) - UNESP, Jaboticabal Campus, for animals suspected to have retinopathies, reduction or loss of visual acuity, or glaucoma, and during the preoperative phase of cataract surgery.

The animals are screened by electroretinography after routine ophthalmic examination based on behavioral tests, on the Schirmer tear test, direct and consensual pupillary test, slit lamp biomicroscopy, plane tonometry, indirect ophthalmoscopy, and fluorescein test. In order to perform a safe ERG and in view of the need for anesthesia, the animals are submitted to general clinical examination, evaluation of cardiorespiratory function, hematology, and biochemical profile.

Dogs prepared for the execution of the ERG are premedicated with levomepromazine hydrochloride ${ }^{a}$ by the intravenous route at the dose of $1 \mathrm{mg} / \mathrm{kg}$, with the total dose not exceeding $25 \mathrm{mg}$.

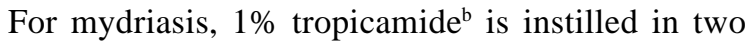
applications separated by a 15 minute interval and the dogs are kept in a dark (scotopic) environment for 20 to 30 minutes. Tyletamine-zolazepam ${ }^{\mathrm{c}}$ is applied intramuscularly at the dose of $1 \mathrm{mg} / \mathrm{kg}$. With the animal in external decubitus, the needle electrodes are applied. The ground electrode is positioned in the region of the occipital protuberance, while the reference electrode is positioned $1 \mathrm{~cm}$ caudally to the lateral eye canthus. After instillation of a $0.5 \%$ proximetacaine

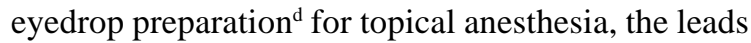
are separated with the aid of a Barraquer blepharostat for cornea exposure (Figure 1).

The corneal electrodes (contact lenses) ${ }^{\mathrm{e}}$ are positioned using a $2.5 \%$ hydroxypropyl methylcellulose solution ${ }^{\mathrm{f}}$ between the corneal surface and the contact lens itself (Figure 1). The animal's head

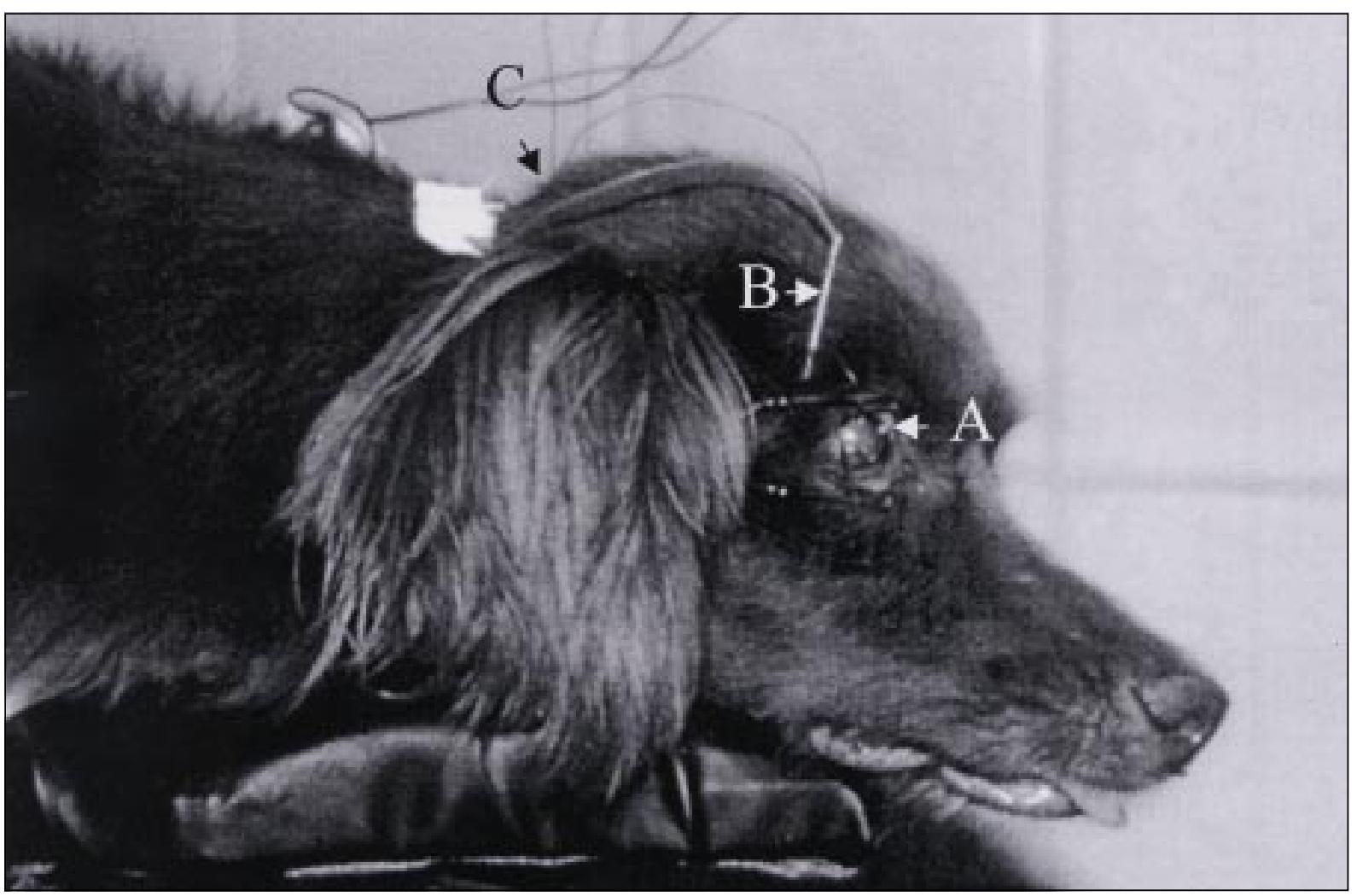

Figure 1 - Photographic image of electrode placement for the electroretinography recordings. (A) Positive electrode, a contact lens containing a fine gold film; a blepharostat is used to obtain eyelid separation. (B) Reference electrode located $1 \mathrm{~cm}$ caudally to the lateral eye canthus. (C) Ground electrode positioned in the region of the occipital protuberance.

Ciência Rural, v. 34, n. 1, jan-fev, 2004. 
is positioned in the Ganzfeld dome (Figure 2) and the tests are started with the scotopic phase in 3 stages, respectively represented by the use of a blue filter (10 $\mathrm{db})$, a red filter $(0 \mathrm{db})$ and a white filter $(0 \mathrm{db})$ for the evaluation of rods, cones and maximum response. In the subsequent phase (photopic), a white filter $(0 \mathrm{db})$ and a flicker at $30 \mathrm{~Hz}$ are used for cone evaluation (Table 2; Figure 3). The responses obtained are recorded and stored on a model EPIC 2000 electroretinography apparatus $^{\mathrm{g}}$ (Figure 2).

The clinical ERG is usually represented by values assigned to implicit time, latency and amplitude of the "a" and " $b$ " waves. Implicit time is the time from the flash to the apex of the "a" wave, latency is the time between the flash and the beginning of the wave, and amplitude is the distance from the base to the apex of the wave (NARFSTRÖM et al., 1995; KOMAROMY et al., 1998b; SIMS, 1999).

Several controllable factors should be considered for the execution of electroretinography since some of them may lead to changes in the measurements for the evaluation of the tracings.
Among them are pupillary diameter, anesthetic type and plane, ambient temperature, equipment, type, intensity and wavelength of the stimulus, intraocular pressure, and adaptation of the retina to luminosity (MILLER, 1993, YANASE \& OGAWA, 1997; KOMARONY et al., 1998b).

In addition to these factors, electrophysiology services should establish a standard pattern for normal individuals of different

Table 2 - Protocol (Classic/Standard) used for flash ERG at the Ophthalmology Unit of the "Governador Laudo Natel" Veterinary Hospital, FCAV - UNESP - Jaboticabal Campus.

\begin{tabular}{lc}
\hline & SCOTOPIC PHASE \\
\hline Blue $10 \mathrm{db}$ & Rods \\
Red $0 \mathrm{db}$ & Cones \\
White $0 \mathrm{db}$ & Maximum cone and rod response \\
& PHOTOPIC PHASE \\
White $0 \mathrm{db}$ & Cones \\
Flicker $30 \mathrm{~Hz}$ & Cones \\
\hline
\end{tabular}

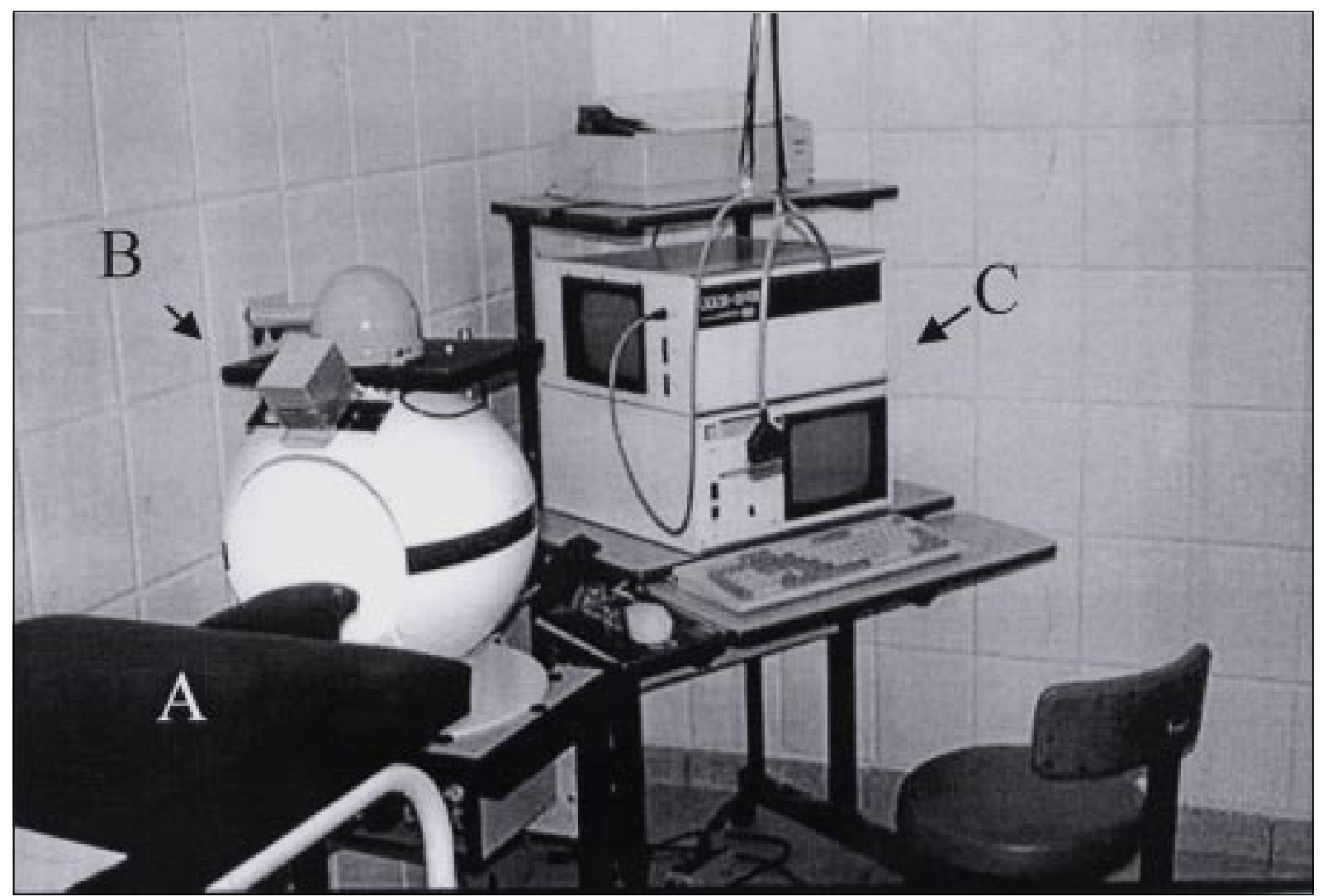

Figure 2 - Photographic image showing the disposition of the equipament utilized to perforn an electroretinogram at the Ophthalmology Unit of the "Governador Laudo Natel" Veterinary Hospital of the Faculdade de Ciências Agrárias e Veterinárias (FCAV) - UNESP, Jaboticabal Campus. (A) Table with a support to the animal's head. (B) Ganzfeld dome. (C) Epic 2000. 


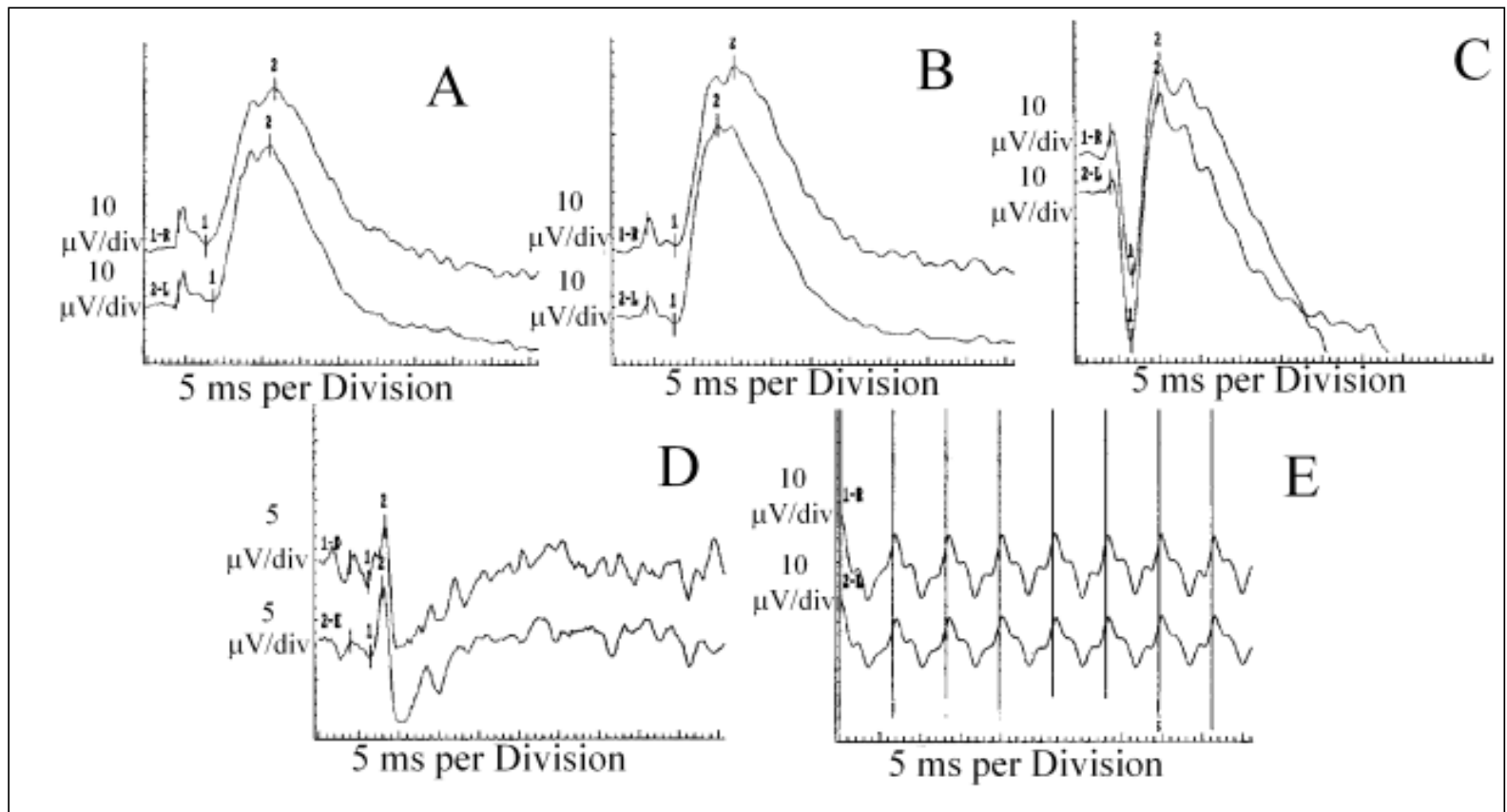

Figure 3 - Example of electroretinogram responses recorded at the Ophthalmology Unit of the "Governador Laudo Natel" Veterinary Hospital of the Faculdade de Ciências Agrárias e Veterinárias (FCAV) - UNESP, Jaboticabal Campus, using the Classic/Standard protocol. Calibration is depicted at the side of the recordings. (A) Scotopic blue $10 \mathrm{db}-$ single flash rod responses after 30 minutes of dark adaptation. (B) Scotopic red $0 \mathrm{db}-$ single flash cone responses. (C) Scotopic white $0 \mathrm{db}-$ single flash maximum cone and rod responses. (D) Photopic white $0 \mathrm{db}$ - single flash cone responses. (E) $30 \mathrm{~Hz}$ cone flicker recording.

species, races and age ranges in order to be able to perform objective analyses of changes in electrical potentials within the various parts of the visual system (NARFSTRÖM et al., 1995; KOMARONY et al., 1998b). Other electrodiagnostic procedures available are the study of evoked visual potentials and of the ERG with a stimulus of checkered pattern (SIMS, 1999).

\section{CONCLUSION}

The electroretinogram is a widely used objective test to assess the outer retinal function. This method is a useful adjunct test for the diagnosis of retinal dystrophies and for pre-operative evaluation of retinal function in conjunction with cataract surgery. To use the ERG diagnostically each laboratory should establish technical procedures that would permit obtain reproducible ERGs under specifically conditions.

\section{SOURCES AND MANUFACTURES}

\footnotetext{
${ }^{a}$ Neozine ${ }^{\hat{a}}$

${ }^{\mathrm{b}}$ Mydriacylâ, Alcon

${ }^{c}$ Zoletilầ50, Virbac do Brasil Ind and Com. LTDA

${ }^{\mathrm{d}}$ Anestalcon ${ }^{\mathrm{a}}$, Alcon
}

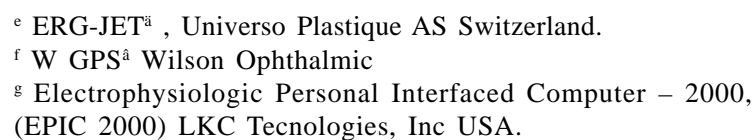

\section{REFERENCES}

AGUIRRE, G.D.; RUBIN, L.F. The early diagnosis of rod dysplasia in the norwegian elkhound. Journal of American Veterinary Medical Association, v.159, n.4, p.429-433 1971 .

AGUIRRE, G.D.; RUBIN, L.F. Progressive retinal atrophy in the miniature Poodle: an electrophysiologic study. Journal of American Veterinary Medical Association, v.160, n.2, p.191-201, 1972.

AGUIRRE, G.D.; RUBIN, L.F. Rod-cone dysplasia (progressive retinal atrophy) in irish setters. Journal of American Veterinary Medical Association, v.166, n.2, p.157-164, 1975.

BROOKS, D.E. et al. Changes in oscillatory potentials of the canine electroretinogram during acute sequential elevations in intraocular pressure. Progress in Veterinary Comperative Ophthalmology, v.2, n.2, p.80-89, 1992.

CARR, R.; SIEGEL, I.M. Electrodiagnostic testing of the visual system: a clinical guide. Philadelphia : F.A. Davis, 1990. 187p.

Ciência Rural, v. 34, n. 1, jan-fev, 2004. 
DANTAS, A.M. Eletrorretinografia. In: DANTAS, A.M. et al. Eletrofisiologia ocular. Rio de Janeiro : Cultura Médica, 1995. 322p.

GUM, G.G.; GELATT, K.N; SAMUELSON, D.A. Maturation of the retina of the canine neonate as determined by electroretinography and histology. American Journal of Veterinary Research, v.45, n.6, p.1166-1171, 1984 .

KOMAROMY, A.M.; SMITH, P.J.; BROOKS, D.E. Electroretinography in $\operatorname{dogs}$ and cats. Part I. Retinal morphology and physiology. Compendium on Continuing Education for the Practing Veterinarian, v.20, n.3, p.343550, 1998a.

KOMAROMY, A.M.; SMITH, P.J.; BROOKS, D.E. Electroretinography in dogs and cats. Part II. Technique, interpretation, and indications. Compendium on Continuing Education for the Practing Veterinarian, v.20, n.3, p.355-365, 1998 b.

MILLER, T.R. The uses and limitations of the electroretinogram in veterinary practice. British Veterinary Journal, v.149, n.3, p.3-4, 1993.

MILliChAMP, N.J.; CURTIS, R.; BARNETT, K.C. Progressive retinal atrophy in Tibetan terriers. Journal of American Veterinary Medical Association, v.192, n.6, p.769-776, 1988 .

NARFSTRÖM, K. et al. Clinical electroretinography in the dog with ganzfeld stimulation: a practical method of examining rod and cone function. Documenta Ophthalmologica, v.90, p.279-290, 1995.

PARSHALL, C.J. et al. Photoreceptor dysplasia: an inherited progressive retinal atrophy of miniature schnauzer dogs. Progress in Veterinary Comperative Ophthalmology, v.1 n.3, p.187-203, 1991.
RUBIN, L.F. Clinical electroretinography in dogs. Journal of American Veterinary Medical Association, v.151, n.1, p.1456-1469, 1967.

SIMS, M.H. Electrodiagnostic evaluation of vision. In: GELATT, K.N. Veterinary ophthalmology. 3.ed. Philadelphia : Lippincott Williams \& Wilkins, 1999. p.483-510.

SIMS, M.H. et al. Effects of stimulus intensity and conditioning on the electroretinogram and oscillatory potentials in darkadapted cats. Progress in Veterinary Comperative Ophthalmology, v.1, n.3, p.177-185, 1991.

SIMS, M.H. Partial masking of the canine electroretinogram by oscillatory potentials - to problem of frequency bandwidth. Journal Veterinary Internal Medicine, v.4, n.1, p.4042, 1990.

VAN DER WOERDT, A.; NASISSE, M.P.; DAVIDSON, M.G. Sudden acquired retinal degeneration in the dog: clinical and laboratory findings in 36 cases. Progress in Veterinary Comperative Ophthalmology, v.1 n.1, p.11-18, 1991

WOLF, E. D.; VAINISI, S.J.; SANTOS-ANDERSON, R. Rodcone dysplasia in the collie. Journal of American Veterinary Medical Association, v.173, n.10, p.1331-1333, 1978.

YANASE, J.; OGAWA, H. Effects of halothane and sevoflurane on the electroretinogram of dogs. American Journal of Veterinary Research, v.58, n.8, p.904-909, 1997.

YANASE, J.; OGAWA, H.; OHTSUKA, H. Rod and cone components in the dog electroretinogram during and after dark adaptation. Journal of Veterinary Medical Science, v.57, n.5, p.877-881, 1995 .

YANASE, J.; OGAWA, H.; OHTSUKA, H. Scotopic threshold response of the electroretinogram of dogs. American Journal of Veterinary Research, v.57, n.3, p.361-3666, 1996. 